\title{
Aktivitas Komunikasi Pemasaran Terpadu (IMC) Pemerintah Kota Ambon Dalam Mengkomunikasikan Brand "Ambon City Of Music" Melalui Kegiatan Tiga Pilar IMC
}

\author{
Arthur Solsolay \\ (art_mergy@yahoo.com) \\ (Fakultas Ilmu Sosoal Ilmu Politik Universitas Sebelas Maret)
}

\begin{abstract}
Ambon city is one of the tourist destinations in the province of Maluku, kept the charm and appeal of natural, historical, religious, culinary, education, art, culture and customs. To develop and trigger the development of musical art in the city of Ambon, Ambon city government felt the need to form a brand that became a brand differentiator and became icons of tourism in Ambon. Brand "Ambon City of Music" was initiated in hopes of becoming a starting point for the development of city Ambon become more competitive through an integrated marketing communications activities in brand communication. Research to describe and analyze the concept of the three pillars of IMC in the steps taken by the Government of Ambon in communicating the brand "Ambon City of Music". other research method used is descriptive qualitative case study approach. R esearchers found that the government has made strategic moves in IMC pillar concept is to approach audiences (government, private sector / stakeholder, elements of the community) and the media (elements of the marketing communication mix).
\end{abstract}

Keywords : Brand, Ambon City Of Music, IMC

\section{Pendahuluan}

Persaingan dunia yang semakin sengit membuat seluruh negara berlomba untuk berebut sumber daya, relokasi bisnis, investasi asing, pengunjung dan penduduk. Dibutuhkan strategi yang berkonsentrasi menghasilkan dan mempertahankan keunggulan kompetitif. Dalam konteks ini, Kotler (2002:253) menekankan pentingnya suatu negara untuk menciptakan sumber keunggulan bersaing salah satunya dengan mengoptimalkan kompetitif bangsa melalui pembangunan sektor unggulan secara terintegrasi.

Terkait dengan konsep keunggulan kompetitif bangsa, pakar strategi bersaing. Michael Porter mengatakan bahwa kemakmuran nasional itu dibuat, tidak diwariskan. Lebih jauh dikatakan bahwa keunggulan kompetitif suatu negara merupakan kapasitas suatu negara untuk menarik perusahaan (baik lokal maupun asing) menggunakan negara tersebut sebagai platform bisnis, secara garis besar harus mempunyai tiga langkah strategis. Pertama menjadi tuan rumah yang baik (Be a good host) bagi pelanggan daerah. Kedua, memperlakukan mereka secara baik (Treat your guest properly). Dan terakhir, membangun sebuah "rumah" yang nyaman bagi mereka (Building a home sweet home).

Dalam menghadapi kondisi tersebut, penting bagi sebuah kota untuk memiliki branding (pencitraan) sebagai arah gerak pembangunan kota tersebut dalam konteks global, bukan hanya konteks lokal. Konsep branding pada negara-negara di Asia bisa lihat pada Singapura dengan profesionalisme yang dibangun lewat Singapore Tourism Board, Uniqeuly Singapore yang menggantikan slogan lama mereka New Asia mampu menyedot jutaan orang (lebih dari 7,6 juta orang) untuk datang berkunjung ke Singapura dan menghabiskan jutaan dollar. Untuk apa saja? yaa untuk berwisata, 
apakah itu wisata belanja, kesehatan dan melanjutkan pendidikan. Singapura merupakan satu contoh konsep branding yang mampu menarik wisatawan asing datang dan memberikan keuntungan bagi Singapura.

Setelah krisis ekonomi melanda Indonesia pada tahun 1997, banyak daerah yang tidak mampu membiayai kebutuhannya sendiri sehingga disubsidi oleh pemerintah pusat. Semenjak Undang-Undang No. 22/1999 tentang Otonomi Daerah (yang kemudian direvisi menjadi Undang- Undang No. 32/2004) diberlakukan, setiap daerah diharuskan untuk aktif dan kreatif dalam memperoleh pendapatan daerah untuk meningkatkan pembangunan ekonomi.

Pemerintah menarik investor dengan banyak cara seperti membuka area industri, membangun banyak pusat bisnis, dan membuat hiburan/pertunjukkan atau sektor jasa lainnya. Dengan demikian, pemerintah bekerja keras untuk membuat kota mereka bertahan dalam menghadapi krisis ekonomi (Nureaini,2010).

Usaha mem-branding daerah telah diterapkan dibeberapa kota di Indonesia seperti Jogja dengan " The Never Ending Asia " menawarkan pengalaman yang tidak akan pernah habis terutama industri kreatif yang berlandaskan kebudayaan tradisional jawa (Kerajaan Mataram Islam), Bali dengan " Shati, Shanti, Shanti " kota yang memiliki daya tarik industri kreatif yang berlandaskan budaya lokal yang tergabung dengan rasa spiritual yang tinggi, hal tersebut tidak hanya tampak pada logo city branding Bali tetapi juga didukung kegiatan-kegiatan yang daerah kemudian mencoba membuat banyak program untuk bersifat lokal seperti pagelaran seni tari, seni peran, seni ragam hias sebagai pelengkap interior dan eksterior, dll. Jakarta dengan " Enjoy Jakarta "dikenal sebagai ibu kota dengan menawarkan gemerlap industri hiburan dan penyiaran yang sarat dengan inovasi dan kreativitas, Solo dengan; The Spirit of Java ", yang menyuguhkan kearifal lokal budaya aslinya dan keramah tamahannya dengan berbagai cultural event, Semarang; The Beauty of Asia, Surabaya ; Sparkling Surabaya .

Pemerintah Kota Ambon juga berusaha untuk mem-branding daerahnya. Sebagai ibu kota propinsi Maluku. Ambon adalah sebuah kota kecil di Indonesia bagian timur yang sarat akan ragam adat-istiadat, bahasa, budaya, seni, dengan pesona alam yang eksotik dan memukau.

Kota Ambon memiliki potensi yang besar dalam pengembangan musik. Kota ini telah banyak melahirkan penyanyipenyanyi handal dan profesional yang terkenal di tingkat nasional bahkan di dunia. Bukan hanya bernyanyi tapi juga bermusik lewat musik tradisi seperti hawaian, musik bamboo, zawat, totobuang, musik jazz, reagee dan musik etnik lainnya. Hal inilah yang membuat kota Ambon disebut-sebut sebagai gudangnya penyanyi dan pemusik. Musik telah menjadi identitas kota Ambon.

Gubernur Maluku, Karel Alberth Ralahalu bersama Walikota Ambon, Richard Louhenapessy, telah me- launching "Ambon City of Music " atau Ambon sebagai kota musik pada tanggal 7 Oktober 2011. Ini adalah sebuah merek bagi kota Ambon. Sebagai tanda dan ikon bahwa Ambon adalah kota musik, maka dibangun sebuah monument di lokasi desa Hative Besar yang bertuliskan "Ambon City of Music" bersamaan dengan digelarnya Ambon Jazz Plus Festival pada bulan oktober 2012.

Kota Ambon mungkin saja bisa dikatakan tertinggal dari kota-kota lainnya di Indonesia dalam menarik kunjungan wisatawan, bukan karena Ambon tidak memiliki daya tarik seperti kota-kota lain, tetapi lebih karena promosi dan brand image development Ambon yang sangat kurang. Kota Ambon memang diuntungkan karena menjadi pusat perdagangan, 
perekonomian, pendidikan, hiburan dan menjadi tempat persinggahan ketika orang ingin bepergian ke beberapa tempat baik di kabupaten-kabupaten dalam provinsi Maluku ataupun Provinsi Papua. Dengan demikian munculah pertanyaan, seperti apakah konsep pemasaran yang harus dilakukan dalam memasarkan kota Ambon untuk mengejar ketertinggalannya tersebut?

Sebagai sebuah merek, "Ambon City of Music" dapat dipakai dan dimanfaatkan oleh semua komponen pariwisata untuk menjual kota ini. Upaya Brand Communication dapat dilakukan dengan berbagai cara, dan cara penyampaiannya harus diatur sedemikian rupa dengan promosi dan pembentukan brand image "Ambon City of Music" secara intensif dan berkesinambungan.

Pengelolaan sebuah brand menjadi menarik manakala itu dilakukan oleh birokrasi. Seperti yang dikatakan James Q. Wilson dalam bukunya Bureaucracy: What Government Agencies Do and Why They Do It (1989: 376-377) mengatakan bahwa birokrasi berbeda dengan bisnis. Memang demikianlah perilaku birokrasi karena dijalankan oleh para birokrat yang tidak mampu dan terperangkap dalam aturan dan rutinitas resmi. Pemerintah Kota Ambon tidak memiliki sebuah divisi khusus yang bertugas untuk memasarkan brand " Ambon City of Music ", namun kebijakan pimpinanlah yang akan mengintegrasikan dan mengsinergiskan pengelolaan brand tersebut, dalam hal ini Walikota Ambon sebagai CEO (Chief Executive Officer) sekaligus bertindak secara defacto selaku CMO (Chief Marketing Officer). Untuk itu konsep IMC menjadi hal yang utama dalam pemasaran program pemerintah ini dengan mengoptimalkan peran pemerintah untuk mengelola brand communication "Ambon City of Music".

Dalam perkembanannya Pemerintah Kota Ambon membutuhkan program komunikasi pemasaran yang terintegrasi. Perkembangan teknologi informasi yang sangat pesat merupakan pendorong berkembangnya disiplin dan konsep pemasaran. Pada era "Knowledge Based Society" ini, telah mengubah posisi komunikasi sebagai jantungnya kegiatan pemasaran sehingga menimbulkan proses pengintegrasian elemen-elemen komunikasi pemasaran yang dikenal dengan Integrated Marketing Communication (IMC). Seperti yang pernah dikaatakan oleh Don Schultz (1993:20), seorang Profesor dari Northwestern University yang menekuni studi tentang communication integration, branding serta pengukuran finansial dalam bidang pemasaran dan komunikasi, yang juga merupakan tokoh dalam sejarah pemikiran IMC. Menurutnya, IMC telah menjadi salah satu topik penting dalam bidang pemasaran "IMC had become one of the hottest topics in whole marketing arena".

IMC menurut Kliatchko (2005), IMC is the concept and process of strategically managing audience- focused, channelcentered, and results driven brand communication programs over time(IMC merupakan konsep dan proses yang secara strategis mengelola komunikasi merek berdasarkan atas pendekatan khalayak, media, dan hasil sepanjang waktu). Berdasarkan definisi tersebut, IMC berfokus pada dan dibedakan oleh tiga elemen yang disebut sebagai pilar IMC, yakni audiencefocused, channel-centered, dan resultdriven. Audience-Focused, berarti Program IMC harus ditujukan kepada semua pasar (multiple-markets) yang memiliki interaksi dengan perusahaan; Channel-Centered, berarti melibatkan pendekatan yang terintegrasi atas perencanaan dan pengelolaan channel yang tepat dan bervariasi dari berbagai elemen komunikasi - seperti advertising, public relations, direct marketing, sales promotions, internet dan 
semua sumber informasi lain serta titik kontak merek - guna membangun dan berhubungan secara harmonis dengan target audience. Result-Driven, berarti program IMC harus dapat diukur dan dihitung sebagai hasil bisnis melalui proses valuasi konsumen dalam pasar yang telah diidentifikasi berdasarkan estimasi terhadap investasi konsumen (ROCI-Return on Customer Investment).

Dinas Pariwisata, Kebudayaan, Pemuda dan Olah Raga merupakan institusi yang mendapat tanggungjawab teknis dalam pengembangan program "Ambon City of Music". Dalam rencana strategis Dinas Pariwisata, Kebudayaan, Pemuda dan Olah Raga Kota Ambon tahun 2011-2016 telah ditetapkan beberapa program Pengembangan Pemasaran Pariwisata yang mendukung pengembangan musik di kota Ambon dengan kegiatan Pembuatan jadwal event budaya lokal, pengadaan media reklame, Promosi dalam dan luar negeri, program pengembangan kemitraan dengan kegiatan Ambon Jazz International.

Dari data jumlah kunjungan wisatawan yang ada, tercatat bahwa terdapat beberapa event berskala nasional dan internasional turut menyumbang angka kunjungan wisatawan diantaranya yaitu, pada tahun 2012 digelar acara MTQ Nasional dengan peserta berasal dari 33 provinsi, jumlah peserta sebanyak 4.319 orang, pengunjung Ambon Jazz Plus Festival 2014 sebagnyak 3.225 orang, peserta Pesparawi Nasional tahun 2015 berasal dari 34 provinsi berjumlah 6.868. Tahun 2015 yang ditetapkan sebagai tahun kunjungan wisata dengan mengusung tema " Mangente Ambon "turut menyedot wisatawan sebanyak 28.685 orang, yang terdiri dari wisatawan domestik sebanyak 22.000 orang dan mancaenegara sebanyak 6.685.

Usaha mem-branding Kota Ambon tidak lepas dari kemitraan pemerintah daerah dengan pihak swasta dan juga dukungan dari masyarakat luas dari segala lapisan untuk menciptakan citra kota Ambon yang benar-benar layak dikunjungi dan dihuni. Hal ini senada dengan kajian mengenai tata pemerintahan yang baik (good governance) yang gencar dilakukan di Indonesia, terutama setelah reformasi pada tahun 1998. Sekretariat Pengembangan Kebijakan Nasional Tata Kepemerintahan yang Baik Bappenas - SPKNTB dalam terbitan resminya yang berjudul Penerapan Tata mewujudkan tata pemerintahan yang baik, harus ada keseimbangan peran tiga pilar (pemerintah, dunia usaha swasta dan masyarakat).

Gambaran di atas membawa kita kepada satu pertanyaan yang signifikan, yakni bagaimana Pemerintah Kota Ambon melakukan kegiatan komunikasi pemasaran terpadu (IMC) dalam mengkomunikasikan merek “Ambon City of Music?". Brand ini digunakan untuk menjual kota Ambon kepada 3 pilar good governance yakni Pemerintah, Usaha Swasta dan Masyarakat. Hal inilah yang menjadi fokus dalam penelitian ini kerena memasarkan sebuah brand menjadi unik manakala itu dilakukan oleh sebuah organisasi birokrasi yang tidak semata untuk menciptakan keuntungan (profit) tetapi juga untuk kemaslahatan dan kemajuan suatu kota, mengingat pemasaran selama ini dikenal sebagai aktivitas yang tidak terpisahkan dari dunia bisnis.

\section{Metode Penelitian}

Penelitian ini dilaksanakan di Pemerintah Kota Ambon, yang sejak oktober 2011 telah dicanangkan sebagai kota musik oleh Gubernur Maluku Karel Albert Ralahalu dan Walikota Ambon Richard Louhenapessy. Objek penelitiannya adalah pada Dinas Pariwisata, Kebudayaan Pemuda dan olah Raga sebagai SKPD yang menyusun program dan aktifitas promosi, pemasaran dan pengembangan dalam bidang pariwisata khususnya terkait program , 
Ambon City of Music “.Jenis penelitian yang digunakan adalah deskriptif kualitatif dengan pendekatan studi kasus. Menurut Lofland (Moleong, 2007: 157), sumber data utama dalam penelitian kualitatif adalah katakata dan tindakan, selebihnya adalah data dokumen dan lain-lain. Data kualitatif merupakan data atau informasi yang paling utama digali dan dikumpulkan serta dikaji untuk keperluan penelitian ini. a) Data Primer. Data Primer adalah data yang dikumpulkan peneliti langsung dari objek penelitian. Dalam penelitian ini data diperoleh secara langsung dari narasumber atau informan di lokasi penelitian, diantaranya dengan Tanya jawab atau wawancara dan melihat secara langsung kegiatan-kegiatan yang teradi di lokasi penelitian. b) Data Sekunder. Data sekunder yaitu data yang diperoleh dari objek penelitian melalui dokumen, arsiparsip,statistik, grafik dan sebagainya yang ada hubungannya dengan penelitian ini. Data dimaksud untuk melengkapi data primer. Teknik pengumpulan data dalam penelitian kualitatif ini terbadi atas tiga, yaitu: Wawancara Mendalam (Indepth Interviewing), Observasi Langsung, Metode Dokumenter (Library Research)Validasi data diambil tiga yaitu : Triangulasi data, Peer riview, Thick description. Teknik analisis data yaitu meliputi : Data Reduksi (Reduksi Data), Data Display (Penyajian Data), Conlusion Drawing / Verifikasi

\section{Hasil dan Pembahasan}

1. Kegiatan Pilar IMC Audience

Focused : Pemerintah Dalam membangun merek "Ambon

City of Music", Pemerintah Kota Ambon turut melakukan komunikasi merek kepada pihak internal, yakni dengan mengambil kebijakan dan melakukan berbagai kegiatan yang melibatkan pegawai Pemerintah Kota Ambon agar dapat mempresentasikan merek "Ambon City of
Music" kepada khalayak/publik dengan baik. Walikota Kota Ambon dalam beberapa kali sambutannya pada acaraacara resmi dan juga pada saat apel pagi menginstruksikan seluruh pegawai SKPD yang ada di lingkup Pemerintah Kota Ambon agar mendukung program "Ambon City of Music" melalui kegiatan-kegiatan maupun aktifitas sehari-hari di lingkup perkantoran atau SKPD. Oleh karenanya, kegiatan yang dilakukan oleh SKPD berkaitan langsung maupun tidak langsung dalam program "Ambon City of Music". Berikut berbagai aktivitas internal branding yang dilakukan oleh Pemerintah Kota Ambon : 1. Pada minggu ke III bulan berjalan dilakukan kegiatan senam pagi, jalan sehat dan Ambon Musik Ceria. Pada minggu ke III ini biasanya dikondisikan sesuai dengan situasi dan kondisi dan biasanya bergiliran. Kegiatan Ambon Musik Ceria ini diisi oleh penyanyi dan pemusik lokal dan yang berpartisipasi dalam kegiatan ini juga adalah pegawai pada beberapa SKPD. Kegiatan ini cukup mendapat rerspon positif dan antusias dari seluruh pegawai yang ikut terlibat dan menyaksikan kegiatan ini. Kegiatan Ambon Music Ceria ini juga menarik masyarakat sekitar ikut menonton karena dilakukan di halaman apel Pemerintah kota Ambon dan berlangsung selama hampir 2 jam.

2. Dalam rangka menjelang HUT Kota Ambon yang jatuh pada 7 september, oleh panitia dilaksanakannya lomba nyanyi lagu daerah antar SKPD yang berpusat di lantai 7 Kantor Walikota. Setiap SKPD diwakili oleh 1 atau 2 orang pegawai dan disiarkan oleh stasiun TV lokal TVRI Ambon. Kegiatan ini memang sudah dilakukan sejak Walikota lama yaitu, Bpk. M. J Papilaja, namun sempat terhenti dan dilanjutkan kembali pada tahun 2012. Kegiatan ini dibawah tanggungjawab assisten III.

3. Pada beberapa acara-acara resmi 
protokoler Waliokota, baik itu acara seremonial maupun beberapa agenda dengan DPRD, lingkup SKPD dan juga acara-acara resmi kedaerahan, ramah tamah, jamuan makan yang dilakukan Pemerintah Kota Ambon, selalu dibuka dengan penampilan musik tradisi seperti musik hawaian penampilan orchestra bamboo dan penampilan beberapa musisi lokal.

4. Kantor Kecamatan Leitimur Selatan pada tahun 2012 dan 2013 melakukan program kegiatan pencarian bakat loba Banding Nyanyi " Leitumur Idol “. Kegiatan ini diikuti oleh masyarakat yang ada dienam desa dalam wilayah kecamatan Leitumur Selatan yaitu, Desa Rutong, Hukurilla, Naku, Kilang, Ema, Hutumury. Hal serupa juga dilakukan oleh empat SKPD Kecamatan lainnya yang melaksanakan kegiatan Seperti Pesparawi tingkat kecamatan dan Pencarian bakat serupa. Komitmen Pemerintah Kota Ambon menjadikan Ambon sebagai kota musik ditunjukan dengan membuka ruang sebesarbesarnya untuk event-event yang akan dilakukan. Dan juga memberikan kemudahan dalam pemberian ijin. Sebagai salah satu bentuk dukungan juga pemerintah kota Ambon menyiapkan anggaran Rp 50.000.000,- ( lima puluh juta rupiah) sebagai stimulant bagi setiap event organizer yang akan menyelenggarakan kegiatan. Akan tetapi ada sebuah kebijakan yang dikeluarkan oleh pemerintah kota yaitu, agar eventevent yang dilakukan tidak lagi mendatangkan artis dari luar namun diisi dengan penyanyi atau musisi dari dalam Kota Ambon sendiri, sehingga sumber daya yang ada di masyarakat kota ambon ini kita berdayakan dan kita tingkatkan kualitas mereka.

Aktifitas pemerintah kota tidak hanya sampai pada level didaerah, namun juga pada level nasional yaitu dengan melakukan road show ke beberapa tempat seperti Jakarta dan suarabaya, sekaligus meminta dukungan dari Kementerian Pariwisata dan ekonomi Kretaif. Road show ini dilakukan dengan maksud menarik perhatian dan partisipasi dari para seniman dan penyanyi asal Maluku yang sementara meniti karir diluar Ambon.

Dinas PKPO, sebagai SKPD teknis dalam pengelolaan kepariwisataan, menetapkan program kegiatan dalam Renstra Dinas terkait " Ambon City of Music “(2011-2016) :

- Pengadaan Materi Promosi

- Pembuatan Jadwal Event Budaya Lokal

- Pengadaan Media Reklame

- Promosi Dalam dan Luar Negeri

- Ambon Jazz International

- Festival Paduan Suara antar SMA / SMK Se-Kota Ambon

- Festival Seni Budaya Daerah

- Ramadhan fair menyongsong bulan suci Ramadhan

- Festival suling bambu

- Kolaborasi musik Hawaian dan Totobuang

- Penyelenggaraan Pagelaran Seni

2. Kegiatan Pilar IMC Audience

Focused : Swasta dan Stakeholder

Dunia Usaha Swasta menjadi salah satu relevant public dalam program "Ambon City of Music", Hal ini disebabkan terdapat beberapa kegiatan dan kebijakan yang telah diterapkan dan sudah dikelola oleh pihak Swasta. Oleh karena itu, pengembangan program Komunikasi Pemasaran Terpadu (IMC) " Ambon City of Music " juga melibatkan peran aktif Dunia Usaha Swasta.

- Perhotelan, restaurant dan café : Menyertakan acara live music, membuat konsep musik pada saat event-event nasional, memberikan kesan kenyamanan. 
Stakeholder :

- Mengadakan event dan pentas musik di Mall, suguhan musik di bandara Pattimura

- Para EO mengadakan Ambon jazz Plus Festival (AJPF) rutin tahunan dan bulanan.

- PAPPRI (Pesatuan Artis Penyanyi Pencipta Lagu dan Pemusik Indonesia), melakukan dialog dalam rangka pendirian institusi musik dan memberikan ide dan konsep.

- Universitas Pattimura telah menggagas pembukaan Prodi Seni Musik pada salah satu fakultas.

- Para seniman dari dalam dan luar turut mendorong dan memberikan masukan terkait strategi pengembangan musik di Kota Ambon (pendirian rumah musik beta), digagas oleh Glen Fredly.

3. Kegiatan Pilar IMC Audience

Focused: Swasta dan Stakeholder Keterlibatan Masyarakat dalam komunikasi merek "Ambon City of Music" dapat dilihat dari berbagai dukungan dan kegiatan Komunikasi Pemasaran Terpadu (IMC) yang dilakukan oleh masyarakat maupun elemen-elemen masyarakat seperti komunitas, kelompok paduan suara, kelompok musik tradisional, organisasi keagamaan.

Pemerintah Kota Ambon terus mengembangkan Program "Ambon City of Music" dengan prinsip "Community Based Tourism" dalam arti benar-benar pariwisata tumbuh bersama-sama masyarakatnya. Masyarakat sebagai target audience, memiliki peran sebagai garda terdepan dalam menggerakan masyarakat untuk memajukan seni musik dengan berbagai inovasi dan kreasi di Kota Ambon. Kehadiran para komunitas dan organisasi kemasyarakat, keagamaan memang memiliki dampak positif yang berpengaruh terhadap pembentukan image Ambon City of Music. bahkan telah memberikan prestasi di kancah nasinal dan internasional.

Komunitas seperti Hip-Hop

Community, Loleba dan Maluku Chamber Carol hampir setiap tahun berkunjung ke Belanda untuk beberapa event.Kelompok Paduan Suara yang tampil pada ajang Pesparawi (Pesta Paduan Suara Gerejawi) selalu mendapat juara. Unsur-unsur masyarakat seperti Tim Penggerak (TP) PKK, pengurus RT/RW dan tokoh masyarakat menjadi garda terdepan dalam menggerakan masyarakat untuk memajukan seni musik di Kota Ambon. Pentas seni musik TrotoArt yang digagas muda-mudi komunitas Loleba, dengan menampilkan atraksi musik di jalanan.

\section{Kegiatan Pilar IMC Channel} Centered

a. Iklan

- Iklan Cetak media massa ( Surat kabar Lokal : Ameks, Siwalima)

Sesuai temuan peneliti, periklanan terkait " Ambon City of Music " pada surat kabar berisi tentang opini atau pemberitaan tentang aktifitas, program pemerintah, kejadian-kejadian penting maupun hal-hal yang terjadi yang telah berlangsung dan akan berlangsung dalam masyarakat yang ada hubungannya dengan seni atau musik. Bentuk tulisan bisa berupa berita, feature, atau artikel yang sifatnya bisa informatif, eksplanatif, interpretatif, persuasif, argumentatif, dan eksploratif.

\section{Radio)}

- Iklan di Media Elektronik (Televisi,

Televisi kebanyakan menampilkan program acara berupa peristiwa- peristiwa atau acara yang dilakukan oleh pemerintah, EO maupun stakeholder, secara live maupun tidak. Untuk iklan suatu event atau acaraacara tertentu biasan Iklan melalui media radio pun kerap dilakukan oleh Pemerintah Kota Ambon, terutama pada saat ada event- 
event yang dilakukan. Pada media radio pun biasa disampaikan secara detail tentang informasi pelaksanaan suatu event baik itu waktu, tempat, pengisi acara dan bahkan penjualan tiket pun melalui media radio.

- Produk

Dari hasil pengamatan peneliti, produk yang melebelkan symbol atau logo maupun tulisan Ambon City of Music atau Ambon Kota Musik barulah sebatas pada produk baju kaos. Baju kaos yang bertuliskan Ambon City of Music ini di cetak oleh pengusaha- pengusaha menengah dan kecil yang biasanya memiliki kelompok-kelompok di bidang pencetakan/sablon baju kaos khas daerah Maluku.

- Media Luar Ruang

Iklan dengan media luar ruang digunakan Pemerintah Kota Ambon untuk mempromosikan "Ambon City of Music" diantaranya adalah Papan Reklame dan ruang pemasangan iklan yang dimiliki oleh Pemerintah Kota Ambon. Iklan media ruangan yang dipakai yaitu menggunakan baliho, spanduk yang terpasang pada papan reklame dan ruang pemasangan iklan. Iklan yang ditampilan adalah berupa informasi mengenai moment, event, peristiwa, acara, maupun aktifitas- aktifitas yang diselenggarakan pemerintah, Stakeholder, masyarakat dan organisasi-organisasi baik yang bersifat kultural, nasional dan internasional.

b. Promosi Penjualan

- Bazaar dan Pameran Dagang

Pemerintah Kota Ambon kerap mengikuti kegiatan ditingkat nasional yang diselenggarakan di lingkup Pemerintah Provinsi, DKI Jakarta maupun di daerahdaerah lain di Indonesia seperti Jakarta Fair dan Indonesia Expo, dan juga Pameran Dagang yang dilakukan oleh Provinsi Maluku c. Acara dan Pengalaman

- Festival dan Event

- AJPF (Ambon Jazz Plus Festival)

- Festival Paduan Suara

- Festival Band Bocah

- Festival Bulan Seni Budaya Daerah

- Ramadhan Fair

- Lasqi atau Festival Qasidah

- Ambon Musik Festival

- Festifal Suling Bambu

- Kolaborasi Musik Hawaian dan Totobuang

- ADJSF (Ambon Desember Jazz Sesion Festifal)

- Agenda Wisata dalam Rangka Program “ Mangente Ambon 2015 “

\section{d. Hubungan Masyarakat/PR dan} Publikasi

a. Pidato

Dalam pidato/sambutan baik yang dilakukan oleh Pemerintah dari tingkat Kota, kecamatan, hingga Kelurahan selalu menekankan tentang promosi "Ambon City of Music".

\section{b. Seminar}

- Lokakarya Pendirian Program Studi Seni di Universitas Pattimura yang dihadiri oleh pembicara antara lain Sekretaris Kota Ambon Drs. A.G. Latuheru, M.Si Rektor Unpatti Prof. DR. Ir. Thomas Pentury, M.Si dan Prof. DR. Jhon Piris, MH dari unsur Legislatif (DPD RI) serta seniman asal Maluku. Tema lokakarya tersebut adalah Harmony From Small Island atau Harmoni dari Pulau-pulau Kecil.

- Forum Group Discussion (FGD), yang dilakukan antara Badan Ekonomi Kreatif (Be Kraf) RI, dengan Pemerintah Kota Ambon dan Para Seniman.

- Walikota Ambon kerap memberikan sosialisasi dan himbauan kepada para pelaku usaha, pengusaha, pelaku seni pada pertemuan atau moment tertentu yang dilakukan Walikota dalam berbagai 
pengambilan kebijakan dan penerapan aturan

- Dialog Masyarakat bertema

"Penggalian Potensi Masyarakat dalam Mendukung “ Ambon City of Music."

- Dialog bertemakan " Baku Dapa, Stori-stori dan Demo Musik”.

c. Hubungan Komunitas

- Komunitas Les Mollucans

- Mullucan Hip-Hip Comunnity

- Kelompok Musik totobuang Kusukusu, Naku, dan Amahusu

- Paparissa Ambon Bergerak

- Komunitas reagee Maluku yakni, Molucca Reggae Community (MoRCy).

d. Publikasi

Keterlibatan media massa dam elektronik dalam mempromosikan "Ambon City of Music" berperan aktif sebagai mitra pemerintah Kota Ambon. Yang dilakukan baru sebatas media lokal. kemunculan berita diupayakan setiap seminggu sekali melalui liputan mengenai event-event atau segala aktifitas yang ada terkait "Ambon City of Music". Oleh karena itu, Dinas Pariwisata, Kebudayaan, Pemuda dan Olah Raga terus berkoordinasi dengan bagian Humas dalam menghadirkan wartawanwartawan media massa dan elektronik untuk meliput kegiatan yang kami lakukan. Memang untuk publikasi adalah bagiannya humas, namun karena kegiatannya adalah dalam lingkup Dinas Pariwisata, maka kehadiran Humas dalam hal peliputan menjadi satu paket bagian yang penting.

\section{e. Loby}

- Lobi dengan kementerian Pariwisata dan Ekonomi Kretaif terkait dengan program-program Pariwisata. Hasil lobi yang tercapai yaitu dukungan Kementerian dengan memberikan bantuan dana untuk kegiatan " Tahun Kunjungan Wisata 2015 "dengan kucuran sebesar lima milyar rupiah.

- Pemerintah Kota Ambon melakukan komunikasi dan melobi dengan Pemerintah pusat terhadap salah satu agenda nasional yaitu dengan diselenggarakannya Assosiasi Pemerintah Kota Seluruh Indonesia, sehingga kota Ambon menjadi tuan rumah 2 kali dalam kurun waktu 3 tahun.

- Pesparawi Nasional juga merupakan salah satu lobi pemerintah kota Ambon dan pemerintah provinsi dengan pihak penyelenggara pusat. Karena sebelumnya juga telah dilaksanakan MTQ tingkat nasional di Ambon.

e. Pemasaran Langsung dan

Pemasaran Interaktif

- Situs Web

Membangun website "Ambon City of Music" memang belum dilakukan oleh Dinas Pariwisata, Kebudayaan, Pemuda dan Olah Raga dan Bagian Humas Kota Ambon maupun KPDE (Kantor Penggelolaa Data Elektronik). Namun web site yang disediakan adalah secara umum yaitu portal resmi pemerintah Kota Ambon, ambon.go.id. maupun melalui google.

f. Pemasaran dari Mulut ke Mulut (WOM) melalui Social Media

Dalam memasarkan "Ambon City of Music" belum menggunakan social media secara optimal. Bentuk media yang saat ini digunakan yang dikelola oleh Bagian Humas Kota Ambon yaitu membuat room atau group pada facebook dengan anggota terdiri dari Sekretaris Kota Ambon, kepala-kepala SKPD, pegawai dan juga masyarakat. Dalam chat room atau group facebook tesebut dipublikasikan setiap kegiatan- kegiatan yang dilakukan dan prestasi yang diraih dengan menampilkan topik utama sesuai dengan agenda pemerintah kota Ambon 
yaitu :

1. Ambon bersih disiang hari.

2. Ambon terang dimalam hari.

3. Ambon tertib transportasi dan perparkiran.

4. Ambon berkualitas dalam pelayanan publik.

5. Ambon yang partisipatif dan komunikatif.

\section{Pembahasan}

Hasil temuan yang peneliti coba paparkan berkaitan dengan teori yang sudah disajikan pada bab sebelumnya adalah, Pemerintah Kota Ambon sedang melakukan proses dan manajemen konsep untuk membangun persepsi tentang kandungan nilai yang ada pada " Ambon City of Music "melalui seluruh target yang ada baik konsumen maupun non konsumen yang dipandang memiliki kontribusi dalam membentuk ekuitas merek dengan menggunakan elemen-elemen komunikasi secara efektif dan efisien guna kepentingan jangka panjang dalam mencapai tujuan. (Estawara, 2008). Hal ini juga peneliti pandang sesuai dengan konsep yang dicetuskan oleh Levitt dan kemudian diperbarui oleh Schultz dan Schultz yang kemudian konsepnya berorientasi pada pelanggan dan aktifitas pembelian.

Segala aktifitas diciptakan untuk menginteprestasikan bahwa Kota Ambon layak dihuni dan dikunjungi dan menjadi tempat atraksi yang aman dan nyaman bagi setiap pengguna dan khalayak. Seperti yang disampaiakan oleh pakar strategi Michael Porter bahwa yang pertama, sebuah negara harus menjadi tuan rumah yang baik (be a good host) bagi pelanggan, kedua memperlakukan mereka secara baik (treat your guest properly), dan ketiga, membangun sebuahu rumah yang nyaman bagi mereka (bulding a home sweet home).Dalam era informasi dewasa ini, yang dapat dilakukan oleh perusahaan hanyalah menawarkan proposisi nilai atas hipotesisnya tentang pasar. Proposisi nilai, berdasarkan pendekatan komunikasi dapat dikatakan sebagai pernyatan tentang "ide". Ide lebih dari sekedar produk, melainkan "become" (menjadi). Ini persoalan beyond the product, ini merupakan intangible aspect dari produk. Aspek-aspek yang dikembangkan di luar produk inti, sebuah gagasan yang dilekatkan pada produk inti, sebuah ide tentang produk yang dilakukan produsen terhadap kepala konsumen, prospek atau pelanggan. Ini merupakan pemasaran yang bersifat intangible. Pada titik ini, sebenarnya pemasaran sudah berbicara mengenai komunikasi. Maka tidak diragukan lagi, proporsisi nilai adalah komunikasi. Apa yang produsen lakukan terhadap kepala konsumen sampai ia mau membeli dan menjadi pelanggan setia produknya, merupakan tujuan komunikasi. Tujuan komunikasi sendiri sebenarnya untuk memengaruhi knowledge, attitude dan practice konsumen terhadap produk (K-A-P Model) (Estaswara, 2008:214).

Konsep dan proses dalam IMC Pemerintah Kota Ambon dibangun dengan membangun komunikasi dan menciptakan aktifitas komunikasi merek kepada para stakeholder, usaha swasta, masyarakat yang memiliki hubungan langsung dengan segala aktifitas dan kreatifitas dalam membangun merek " Ambon City of Music, kemudian melalui media tradisional lokal dan media modern seperti internet yang diharapkan merangsang khalayak untuk melakukan keputusan-keputusan terhadap merek dan juga berorientasi pada hasil dengan target jangka panjang.

Hal ini sesuai dengan konsep yang ditawarkan oleh Kliatchko dalam jurnal International Journal of Advertising 2005. (Estawara, 2008 :90), yaitu bahwa, IMC adalah konsep dan proses yang secara strategis mengelola komunikasi merek 
berdasarkan atas pendekatan khlayak, media dan hasil sepanjang waktu.

Tantangan dalam melakukan Komunikasi Pemasaran Terpadu (IMC) "Ambon City of music" adalah layaknya ketika seorang produser ingin mengomunikasikan seorang artis yang baru mau terkenal tentu berbeda dengan ketika ingin mengomunikasikan seorang artis yang sudah terkenal. "Ambon City of Music" merupakan program dalam memasarakan daerah sekaligus program kepariwisataan yang sudah digaungkan pada tahun 2011, namun destinasi yang terangkum dalam program ini memiliki kearifan lokal yang sudah kuat maka Pemerintah Kota Ambon butuh strategi yang tepat dalam membangun identity "Ambon City of Music" dimulai dari blackbox karakteristik dari potensi yang ada.

Hal ini berkaitan dengan teori Quadruple Helix Model yang dicetuskan perama kali oleh Robert Arnkil dkk pada tahun 2010,2013. Bahwa inovasi yang dilakukan suatu daerah menggunkan interaksi aktif antar empat aktor yakni, pihak akdemik/perguruan tinggi (academis). Pelaku bisnis (business), pemerintah (government) dan masyarakat (community).

Dalam " Ambon City of Music “ program ini merupakan salah satu strategi yang mengangkat isu kearifal lokal yang menjadi keunggulan kompetitif yang secara otomatis hal ini tumbuh dalam tradisi dam aktiftas masyarakat sehari-hari. Pemerintah dalam merancang strategi dan membuat suatu inovasi dalam pengembangan Kota Ambon tentunya menawarkan berbagai program kegiatan serta rencana tindak lanjut yang ketika ditawarkan kepada audience dalam hal ini usaha swasta, stakeholder dan masyarakat, maka ini dapat diterima secara universal karena program kebijakan ini merupakan akar rumput masyarakat.

Dalam penelitian ini peneliti menemukan bahwa, masyarakat dan komunitas memiliki inovasi dan kreasi sendiri dalam menunjukan identitas “ Ambon City of Music “. Masyarakat sebagai level akar rumput bahkan menciptakan ide dan atraksi yang tanpa campur tangan pemerintah pun dapat memberikan pesan kepada khlayak bahkan dunia internasional terhadap eksistensi Ambon sebagai Kota Musik. Ini menunjukan bahwa teori Qudruple Helix tepat dalam melihat masyarakat bukan saja sebagai perantara antara pemerintah, akademisi dan pelaku bisnis, tapi masyarakat juga sebagai pencipita ide, inovasi, pengetahuan dan teknologi yang bisa berbasis pada pengalaman, kebutuhan, budaya atau kearifan lokal. (Fuzi, 2013) Menjadi channel-centered artinya melibatkan pendekatan yang terintegrasi atas perencanaan dan pengelolaan channel yang tepat dan bervariasi dari berbagai elemen komunikasi - seperti advertising, public relations, direct marketing, sales promotion, internet dan semua sumber informasi lain serta titik kontak merek guna membangun dan berhubungan secara harmonis dengan target audience. Dalam mempromosikan "Ambon City of Music", Pemerintah Kota Ambon melakukan strategi pemasaran dengan memutuskan bauran media melalui kerangka dasar komunikasi umum. Yang termasuk dalam kerangka dasar komunikasi umum seperti yang disebutkan Kotler dan Keller dalam bukunya Manajemen Komunikasi (2009:175) yakni Iklan, Promosi Penjualan, Acara dan Pengalaman, Hubungan Masyarakat \& Publisitas, Pemasaran langsung \& Pemasaran Interaktif, Pemasaran dari Mulut ke Mulut, dan Penjualan Personal.

\section{Kesimpulan}

Kegiatan pilar IMC: Audience Focused yang dilakukan oleh Pemerintah Kota Ambon telah melibatkan kesinergisan relevant public dalam tiga pilar pada penerapan Tata Kelola Pemerintahan yang 
baik (Good Governance) yakni Pemerintah, Usaha Swasta dan Masyarakat Kota Ambon. Dalam kegiatan pilar IMC Audience Focused dengan relevant public. Secara internal pemerintah Kota Ambon telah memulai dari diri sendiri dengan terlibat aktif dalam kegiatan komunikasi pemasaran terpadu (IMC) dengan menciptakan suasana dan aktifitas di lingkup Pemerintah Kota Ambon yaitu melalui program kegiatan yang dilakukan, para pegawai, dan rutinitas yang mencerminkan komitmen menjadikan Ambon sebagai Kota Musik.

Berbagai kebijakan dan himbauan dikeluarkan oleh Walikota Ambon dalam mengupayakan penyusunan strategi pesan terhadap para pelaku usaha dan stakeholder sebagai mitra pemerintah Kota Ambon. Selanjutnya komunikasi dibangun sampai ke instansi ditingkat pemerintah Provinsi dan pemerintah pusat yaitu kementerian pariwisata dan ekonomi kreatif. Pada dasaranya sektor swasta dan stakeholder turut mendukung " Ambon City of Music " dan bersedia dilibatkan lebih jauh dalam program ini. Perhotelan turut mempromosikan Ambon sebagai Kota Musik dengan event-event live musik yang dilakukan secara regular dan berkualitas, sama halnya dengan pihak café,restorant yang juga mengusung konsep yang sama dengan menyuguhkan live musik secara rutin dan mendapat respon yang baik ditengah masyarakat.

Masyarakat Kota Ambon secara otomatis menjadi bagian dan menjadi cerminan dari " Ambon City of Music “ dengan menampilkan ciri khas budaya seni yang dibawakan dalam agenda- agenda pemerintah Kota Ambon, acara seremonial maupun aktifitas-aktifitas secara spontan. Bentuk partisipasi yang berjalan insiatif semakin mencerminkan keunggulan kompetitif dibidang musik.Masyarakat sebagai bagian audience focused diberdayakan dengan kreasi- kreasi musik dengan konsep yang modern sehingga membuka lapangan kerja dan menambah semangat berkompetisi di bidang musik baik secara lokal dan nasional bahkan internasional. Komunitas-komunitas, kelompok masyarakat dan organisasi di lingkungan kepemudaan dan keagamaan serta pemangku kepentingan lain seperti musisi dan pekerja musik, ikut menambah kontribusi lewat pemikiran, aktion dan tindakan nyata melalui prestasi-prestasi yang telah diukir dalam ajang-ajang nasional dan internasional.

Pemerintah Kota Ambon secara terintegrasi telah melakukan kegiatan pilar Komunikasi Pemasaran Terpadu (IMC) Channel Centered dengan memutuskan bauran media melalui kerangka dasar komunikasi umum, yakni melalui channel Promosi Penjualan, Acara dan Pengalaman, serta Hubungan Masyarakat \& Publisitas. Sementera itu tiga bauran media yang dilakukan namun belum secara optimal yakni, Iklan, bauran Pemasaran langsung \& Pemasaran Interaktif dan bauran Pemasaran dari Mulut ke Mulut (WOM) melalui media social.

\section{Daftar Pustaka}

Dewi, Ike Janita. (2009). Creating \& Sustaining Brand Equity, Amara Book, Yogyakarta.

Duncan, T. (2002). IMC: Using Advertising and Promotion to Build Brands. The McGraw-Hill Companies, Inc. International Edition. New York.

Durianto, Darmadi. (2001). Strategi Menaklukan Pasar: Melalui Riset Ekuitas dan Perilaku Merek, Gramedia Pustaka Utama, Jakarta.

Estaswara. (2008). Think IMC ! Efektivitas Komunikasi untuk 
Menciptakan Loyalitas Merek dan Laba Perusahaan. Jakarta: PT Gramedia Pusaka Utama.

Hermawan, Agus. (2012). Komunikasi Pemasaran, Jakarta : Erlangga

Sugiyono. (2009). Metode Penelitian Kuantitatif Kualitatif dan $R \& D$, Bandung: CV Alfabeta.

Sulaksana, Uyung. (2003). Integrated Marketing Communications Teks dan Kasus, Yogyakarta: Pustaka Pelajar,

Sutisna, (2001), Perilaku Konsumen dan Marketing Communications (IMC). International Journal of Advertising.

Schultz, D.E dan H. Schultz, (1998), TransitioningMarketing Communication into the Twenty- First Century. Journal of Marketing
Communications. Komunikasi Pemasaran, Bandung: PT.Remaja Rosdakarya.

\section{Jurnal:}

Duncan, T., dan S. Everett, (1993), Client Perceptions of Integrated Marketing Communications. Journal of Advertising Research.

Kitchen, P.J., et. Al (2004) The Emergence of IMC: A Theoretical Perspective. Journal of Advertising. dan D.E. Schultz. (1999). Multi-Country Comparison of the Drive for IMC. Journal of Advertising Research.

Kliatchko, J. (2005). Towards a New Definition of Integrated. 